Mental Health, Religion \& Culture, 2015

Vol. 18, No. 5, 354-367, http://dx.doi.org/10.1080/13674676.2015.1056122

\title{
Suspicious circumcisions: a psychoanalytic exploration of the connection between Antisemitism and Misogyny
}

\author{
Paul Cantz
}

\author{
Department of Psychiatry, University of Illinois at Chicago College of Medicine, 1601 W. Taylor St., \\ Chicago 60612-7347, IL, USA
}

(Received 31 March 2015; accepted 26 May 2015)

\begin{abstract}
The historical dominance of Classical Greek attitudes, beliefs, and meaning structures has directly contributed to the "otherness" status of women, establishing an implicit misogynistic undercurrent in the history of Western society. The privileging of certain Greek ethos within the foundation of Christendom has likewise amplified and institutionalised Antisemitism, solidifying the Jew as an "other", atavistic and vestigial nation of people. The biblical world view, in contradistinction, offers an important reappraisal of masculine and feminine ideals, undercutting misogynistic attitudes and in so doing delimiting space for an authentic feminine other to find expression. The alternative gender conceptualizations endorsed by the Bible and more generally embodied in Hebraic thought render Jews a target for displaced misogynistic rage. Particular attention is given to the domains of rationality vs. irrationality, activity vs. passivity, and the dramatically different ways that the GraecoRoman, psychoanalytic, and Jewish traditions understand ritual circumcision, specifically how after being filtered through a Hebraic lens ritual circumcision can be psychoanalytically re-conceptualised as a potent mechanism for forging intergenerational connectedness.
\end{abstract}

Keywords: biblical studies; circumcision; Oedipus complex; misogyny; anti-Semitism; psychoanalysis

\section{Introduction}

The intellectual dominance of Classical Greek attitudes, beliefs, and meaning structures has directly contributed to the otherness status of woman, establishing an implicit misogynistic undercurrent throughout Western history (Cantz \& Kaplan, 2013). The privileging of certain Greek ethos that are embedded within the foundation of Christendom likewise has amplified and ultimately institutionalised Antisemitism, ${ }^{1}$ solidifying the Jew as an "other", atavistic and vestigial nation of people (cf. Hatch, 1957; Kaplan \& Cantz, 2014). The biblical world view, in contrast, offers a dramatic reappraisal of masculine and feminine ideals, consequently undercutting misogynist attitudes and establishing alternative gender standards that, to date, have not received proper attention in in scholarly circles, particularly as it relates to psychoanalytic metatheory.

\footnotetext{
*Email: pcantz@gmail.com

†Present addresses: Department of Psychology, Adler University Chicago, 17 N. Dearborn St., Chicago, IL; Spertus Institute for Jewish Learning and Leadership, Chicago, IL; University of Aberdeen, Aberdeen, UK.
} 
While appreciating that Antisemitism is derived from an over-determined belief system (both conscious and unconscious), in this paper I argue that an alternative conception of gender ideals endorsed by the Bible and more generally embodied in Hebraic thought renders Jews a target for displaced misogynistic rage, as evidenced by the unmistakable parallels between the manner in which women and Jews have historically been portrayed in Western society. Although many scholars have noted the descriptive similarities between the uncouth characterisations used by misogynists and Antisemites, respectively, there has been a general reluctance to fundamentally link these two sets of attitudes in a theoretically coherent manner. These similarities, however, transcend semantic coincidence and point to an intractable psychological connection.

To support this proposal, Greek and biblical conceptualisations of gender ideals are critically re-examined within the psycho-historical context of the propagation of misogyny and Antisemitism - inarguably two of the oldest and enduring forms of hatreds ever conceived. To unpack the thematic commonalities and underlying psychodynamic mechanisms that link misogyny and Antisemitism, special attention will be given to the domains of rationality vs. irrationality, activity vs. passivity, and, most notably, the dramatically different ways that the Graeco-Roman, psychoanalytic, and Jewish traditions understand ritual circumcision and its relationship to castration anxiety.

\section{Misogyny in ancient Greek thought}

As my co-author Kalman J. Kaplan and I emphasised in a recent essay that contrasted Greek and Hebraic views of femininity (Cantz \& Kaplan, 2013), the ancient Greeks endorsed a world view that veritably considered women as being a race apart (Hesiod, c. 700 BCE, Theogony: 592) ${ }^{2}-a$ species that, unlike their male counterparts, had been fashioned from, "filth and sediment" (Hippolytus's comments in Eurpides' Hippolytus). While Pandora represents the archetypal portrayal of the ancient Greek attitude towards the female, Classical Greek misogynistic inclinations are perhaps nowhere better encapsulated than through the writing of the satirist Semonides of Amorgos (c. 650 BCE). In his work entitled Women, Semonides suggests that the gods crafted different types of women in concordance with vile and base characteristics of different animals and phenomena, such as being emotionally labile, immoral, deceptive and untrustworthy, ugly, hyper-sexualized, lazy, and generally an all-around burden for her husband. (Poem 7). Another ancient Greek poet, Hipponax (c. 540 BCE), likewise recorded numerous degrading aphorisms regarding women, with arguably his most famous being, "Two days are sweetest for a woman, the day a man marries her and the day he carries her out dead."

The Greek historian, soldier, and philosopher Xenophon's (c. 430-354 BCE) famous treatise, On Man and Woman (c. 370 BCE), expresses many of the Graeco-Roman attitudes regarding gender ideals. He begins by recording that the physical constitution with which god endowed man primes him towards outdoor tasks since god, "made the man's body and mind more capable of enduring cold and heat, and journeys and campaigns". For women, Xenophon related that the indoor, private domains of society were regarded as their natural habitat, citing as proof that god meted out to women a disproportionate measure of fear in order to dissuade them from venturing into the public sphere, thereby betraying their primary functions of childrearing and tending to domestic affairs. Vasillopulus (2008) attributes the degradation of women in Athenian society to the twin foundations of the "Phallicratic Polis": the necessity of securing domestic order, and the need to procreate. To this end, O'Neal (1993) has identified the prototypical Athenian wife in the figure of Homer's Penelope, who dutifully stood in wistful passivity waiting for her husband, Odysseus, while he was off warring, adventuring, and adulterating - carrying on with his life which minimised the importance of the nuclear family and institutionally subjugated women. 
Attitudes towards women are one of the few domains that successfully made the crosswalk between Greek mythopoeia and Greek philosophy. For instance, Plato recorded that, "that part of the human race which is by nature prone to secrecy and stealth on account of their weakness-I mean the female sex-has been left without regulation by the legislator, which is a great mistake" (Laws, VI. 781). Although Plato had exclaimed in The Republic (377d) that the poets may lie, here we can see the influence of Hesiod who had warned that, "the man who trusts womankind trusts deceivers" (c. 700 BCE/ 2006). Plato's most famous pupil Aristotle, in his essay On a Good Wife (Economics, c. 330 BCE), likewise affirms that women are metaphysically constrained to a station of subservience, justifying the societal mores by appealing to what he considered a universal truth since the "... laws [were] appointed for her by divine will”. In Politics, Aristotle elaborates these sentiments by explaining that, "the courage of a man is shown in commanding, of a woman in obeying" (1245b, pp. 16-25).

Naturally, one can locate exceptions to these prevailing world views, however tempered they may be. For example, when writing of the Halicarnassian ruler Artemisia, the Greek historian Herodotus (480 B.C.E.) praised her as a "special wonder" for both her military triumphs and wise counsel that she provided to King Xerxes. Herodotus, however, should not be confused with an unsung forerunner of modern feminism, since in the same breath in which he praises Artemisia he asserts that her successes are a result of her "male" virtues, and then attributed a quote to her in which it is depicted expressing an internalised sense of misogyny by proclaiming that, "[the Hellenes] are as much superior to your people in seamanship, as men to women". Herodotus' account concludes with Xerxes proclaiming that, "My men have behaved like women, my women like men!"”

That the ancient Greeks provided enough ammunition for the West to regard women as intellectually and morally inferior to men does not here demand a more extensive explication since it has only been relatively recently in the course of human history that the "second sex" (de Beauvoir, 1949) has been granted equivalent civil rights of which free men have enjoyed for centuries if not longer.

\section{The modern intersection between Misogyny and Antisemitism}

The reach of the ancient Grecian misogynistic conception of woman extended well beyond classical antiquity, indeed fully blossoming across various disciplines during the fin de siècle in the works of such regarded intellectuals as the nihilistic philosopher Friedrich Nietzsche, the Italian positivist criminologist Cesare Lombroso, and the brilliant, though disturbed, Austrian philosopher Otto Weininger ${ }^{3}$.

The historian of philosophy, Will Durant (1926), suggested a direct line from Aristotle's views of women to those endorsed by Nietzsche, and therefore we find Nietzsche's opinions on women echoing many if not most of the misogynistic attitudes of the ancient Greeks:

The Greek culture of the classic age is a male culture. As far as women are concerned, Pericles expresses everything in the funeral speech: "They are best when they are as little spoken of as possible among men"... nothing else was taken into consideration than the production of children and lust; there was no intellectual intercourse, not even real love-making... The women had no other mission than to produce beautiful, strong bodies, in which the father's character lived on as unbrokenly as possible .... (1886/1966, p. 259)

Nietzsche went on to pepper his philosophical career with similar aphorisms which branded women as being constitutionally, “...weak, typically sick, changeable, inconstant...” (1910/ 1968 , p. 864), possessing a, ... dagger-pointed intelligence” (1879/2006, p. 414), and, appealing 
to a pilloried variant of the biblical Eve, asserting that, "From the beginning, nothing has been more alien, repugnant, and hostile to woman than truth" (1886/1966, p. 232).

In La Donna Delinquent: La Prostituta e la Donna Normale (Criminal Woman, the Prostitute, and the Normal Woman, 1903), Lombroso, a contemporary of Nietzsche, lends these philosophical musings an air of scientific authority through a rather meticulously empirical physiognomic investigation of women. Lombroso differentiated "normal" and "criminal" types of women, the latter exhibiting an array of unvirtuous tendencies such as lying, acting duplicitously, and possessing a general moral deficiency that are more numerous and varied than those found in men. In Lombroso's analysis of prostitution he goes on to suggest that all women are latent criminals, essentially putting women's sexuality on trial by asserting that their beauty acts as a façade promoting, "the underlying notion ... of the woman as trickster and as a falsification personified as she seduces her client through her youthful appearance that hide the 'man' underneath" (p. 34). Compare this to Lombroso's treatise L'Antisemitisomo e le Scienze Moderne (Anti-Semitism and Modern Science, 1894) where he indicates that Jews are prone to lying and cleverness, appealing to the stereotype of the duplicitous cheating merchant, such that has been iconified in Shakespeare's character Shylock in The Merchant of Venice.

Drawing on the Athenian discomfort with an integrated sense of female sexuality ${ }^{4}$ that became embodied in the work of Nietzsche and the physiognomic certitude expressed in the work of Lombroso (and mixing in a generous measure of his own unease as well!), Otto Weininger (1903/2005) presented a binary approach towards conceptualising the enterprise of love between a man and a woman: "There is only one love: it is the love for Beatrice, the worship of Madonna ... [and] [f]or sexual intercourse there is the whore of Babylon" (p. 214). Woman, therefore, is either too virtuous, angelic and supra-sexual, like the goddesses Athena, Atlanta, and Artemis (to make little mention of the Virgin Mary ...), or they are hyper-eroticised whores. In Weininger's Graeco-European world view, therefore, woman's sexuality served man as merely " ... a device for masturbation or as a bearer of children" (p. 224). ${ }^{5}$ Weininger's continuum of the female character, which ranged from motherhood on one end of the spectrum to prostitution (in a more generic sense) on the other, echoed Lombroso's description of the female criminal, whose traits, he contended, are to be expressed, albeit in varying degrees, among every woman. We therefore do not need to stretch our imaginations to accommodate for Weininger's notion that, "No woman in the world represent the idea of Woman as perfectly as the Jewess" (italics in the original, p. 289), who amplifies the nefarious character traits of the proto-gentile woman.

Weininger is less generous than Lombroso in his assessment of the intellectual stature of Jews. For instance, in his book The Man of Genius (1891) Lombroso concluded that, "this abundance of Jewish men of genius of the first order is allied with a deficiency of men in the second order of intellect" (p. 135). Weininger focuses more intently on what Lombroso would characterise as Jews of the "second order of intellect", when he asserted that Jews generally lacked the capacity for intellectual depth, which therefore explains why, “... the Jews are unable to produce any really great men and why Judaism, like Woman, is denied the highest degree of genius" (italics in the original, p. 285). Weininger elaborates on this motif and links it to the female character:

The congruency between Judaism and femininity seems to become complete as soon as one begins to reflect on the Jew's infinite capacity for change ... the agility of the Jewish mind, the lack of any deeply rooted convictions - Do these things not prove that both the Jews and women are nothing and therefore can become everything? (italics and emboldenments included in the original, p. 289).

The most female of men, he adds, is the cosmopolitan Jew, who, in his rootlessness and degeneracy, is "saturated in femininity". 6 Weininger explains that Christ was great because he, 
"conquered in himself Judaism, the greatest negation, and created Christianity, the strongest affirmation and the most extreme opposite of Judaism" (p. 297), therefore Jesus' greatness came to pass since, "[t]he redeemer of Judaism is the redeemer from Judaism" (p. 298) - Judaism being the greatest adversary to doubt and the champion of ambiguity. Hitler, an admirer of Weininger's, wryly designated Weininger as a "good Jew", who "killed himself on the day when he realised that the Jew lives upon the decay of peoples" (Roper, 1953, p. 116).

Weininger's final solution to the "female problem" represents the perverted, though internally logical, extension of his view on Judaism ...

A woman who had really renounced, a woman who sought peace in herself, would no longer be a woman. She would have ceased to be a Woman, and she would have at last received the inner baptism in addition to the outer. (p. 313)

Weininger's essential argument is that women must emancipate themselves from their Womanhood similar to how Christ liberated himself from his Judaism. Therefore we find Weininger proclaiming that, "The most inferior man is still infinitely superior to the most superior woman ..." (Weininger, 1903/2005, p. 230, emphasis in original). Weininger's economy of the sexes, which perhaps represents the zenith of mainstream, populist misogynistic thought at the fin de siècle, leads to nothing less than the destruction of the human species! The medical historian Sander Gilman (1991) summarises this attitude by suggesting that in the eyes of European gentiles throughout antiquity and extending until perhaps even today, albeit with slight variations, "The Jew is the hysteric; the Jew is the feminized Other; the Jew is seen as different, as diseased" (p. 333). The wandering Jew is the anthropomorphised "wandering womb". Both the woman and the Jew are accordingly understood as constitutionally and physiognomically inferior in nearly identical ways.

\section{Biblical/Hebraic gender ideals}

Though contemporary feminist critics have generally interpreted the Hebrew Scriptures as an androcentric and patriarchal collection of documents that promotes, "the inferiority, subordination and abuse of women" (Trible, 1990), Cahill (1998) has taken an alternative perspective, suggesting that this line of thinking, “. .. is itself a projection, a sort of feminist wish fulfillment without substantial confirmation in the archeological record" (p. 247). In contrast to the Greek masculine ideal of warring, athleticism, and detached rationality, the Bible does not offer a platonic ideal for either gender, but instead promotes a dynamic multiplicity of valid modes of being, both sharing core characteristics of righteous conduct, scholarship, and trust in a loving God.

We find a descriptive composite of these masculine traits in 1 Samuel (16:13), where David is characterised by one of Saul's servants as, "skillful in playing [the lyre], a man of valor, a man of war, prudent in speech, and a man of good presence, and the Lord is with him" (16:18). Contrary to the work of Clines (1995) who, primarily based on the above description, quite quizzically on the one hand argues that the persona of the biblical King David aligns with patently Greek-based conceptions of the prototypical masculine ideal of the soldiering, aggressive male who is passively interested in female love and more interested in being a cultural and political hero, while in the same breath acknowledging that David also represents a, "distinctive portrait of Hebrew masculinity" (p. 24) by portraying paradoxical gender norms such as moral and intellectual fallibility, crying without worry that his masculinity will be compromised, and irrational faith. Naturally there can be no doubt that the Bible portrays David as a skilled athlete and warrior, but the quality of David's military conquests differs from the unchecked Graeco-Roman sense of imperialism since most of David's battles were fought in the service of national self-defense. Physical strength and the creation of the Hebraic warrior-"hero" was an accident born of necessity - the 
result of being stewards of a sovereign nation state. The ancient Israelites, though being competent in war, did not internally cohere their sense of masculinity around their military acumen. These characteristics figured secondarily in the hierarchy of biblical masculinity and, reading a bit further, we find in Chronicles 22: 7-9 that the Jewish Temple in Jerusalem was prohibited to be built during David's reign/lifetime since he had, "shed much blood", despite the fact that his warring had been conducted in accordance with divine direction.

Taking a step back from the figure of David, we find ample biblical evidence de-emphasising if not outright repudiating characteristics of violence and aggression in males. Take for example Isaac and Rebecca's sons, the twin brothers Jacob and Esau:

And the two boys grew up. Esau became a man knowledgeable about hunting, man of the field, but Jacob was a simple man, dwelling in tents. Isaac loved Esau, because he ate of the hunt; but Rebekah loved Jacob. (Gen. 25:27-28)

When we unpack this verse, we can learn much of the Bible's favourable view of Jacob's personality. When the Bible describes Jacob as "dwelling in tents", this represents an idiom for engaging in scholarly pursuits. The term "simple" to describe Jacob fails to capture the essence of the original Hebrew (tâm), which can also mean "pure", "innocent", and even "perfect". ${ }^{7}$ Later, we find the prophet Malachi vituperating the Edomites (Esau's descendants and nearby neighbours with the Israelites), by hearkening back to their nation's father: "Is not Esau Jacob's brother?" says the Lord, "Yet I have loved Jacob but I have hated Esau; I have laid waste his hill country and left his heritage to jackals of the desert" (Mal. 1:2-3). Though it is important to acknowledge that there exists a national and political context to this verse that does not concern our present inquiry, we nevertheless see how the Bible vilifies the aggressive male and champions the morally righteous scholar as a qualitatively better masculine trait. ${ }^{8}$

Not surprisingly, we also find that both the personas of Moses and Joshua, considered amongst many as two of the greatest leaders of the ancient Israelites in both religious as well as military matters, were likewise acclaimed in the Bible for demonstrating exceeding humility, modesty, obedience, and moral fortitude (cf. Ex. 24:13; Num. 12:3; Num. 14-6-9). ${ }^{9}$ The biblical conception of masculinity, supported by centuries of post-biblical commentary and rabbinic elaboration, affirms a conceptualisation of Hebraic masculinity premised on moral courage, humility, and, above all, faith and trust in a loving God.

\section{An alternative perspective on the psychic correlates between Castration anxiety, Misogyny, and ritual circumcision}

As I endeavor to illustrate later in this section, after accommodating for a Hebraic meaning structure, ritual circumcision can be psychoanalytically conceptualised as a potent mechanism for forging intergenerational security and connectedness. This is in stark contrast to traditional psychoanalytic thinking which equates Jewish ritual circumcision with symbolic castration (see Freud, 1909, 1939; Reik, 1946; Rubenstein, 1968) or even as a wholesale substitute for child sacrifice (Schlossman, 1966). Freud (1909), in a footnote to his Little Hans case study, An Analysis of a Phobia in a Five-Year-Old Boy, makes a somewhat tenuous attempt to link the fear of women with the hatred of Jews by appealing to his theory of castration anxiety, writing:

The castration complex is the deepest unconscious root of anti-semitism; for even in the nursery little boys hear that a Jew has something cut off his penis - a piece of his penis, they think - and this gives them a right to despise Jews. And there is no stronger unconscious root for the sense of superiority over women.

(1909,

p. 
Freud, in a belated footnote added to his essay on Leonardo da Vinci that he had originally published in 1910, further alluded to an association between Antisemitism and misogyny, declaring with even greater confidence that:

The conclusion strikes me as inescapable that here we may also trace one of the roots of anti-Semitism which appears with such elemental force and finds such irrational expression among the nations of the west. Circumcision is unconsciously equated with castration. (1919, pp. 95-96)

In an analysis of a case study of an adult Jewish male, Franz Alexander (1923) likewise affirmed Freud's formulation of emasculated position of the circumcised Jew, underscoring the shame and inferiority experienced as a result of this "primal castration", and the resultant hostility that becomes directed to both the Jew and the woman. Following this line of thought, the circumcised Jew through the symbolic loss of his phallus represents a negated man (i.e., a woman), thereby highlighting that the true source of castration anxiety does not belong to the unconscious fear of castration, ipso facto, but rather it can be traced to the terror of transforming into a feared, "lesser-than" Gorgon-esque creature: the female.

Despite the conclusions drawn from his work with the Little Hans case and his armchair analysis of da Vinci, the manner in which Freud neglected forming a cogent theory that more fully considered the intractable dynamics linking circumcision, misogyny, and Antisemitism remains a curiosity, prompting Jonte-Pace (2001) to observe that, “... [Freud] Stopped short of a full articulation of a theory which anti-Semitism, misogyny, and circumcision/castration anxiety reside in the space of the unspeakable, uncanny body of the mother" (p. 107).

Enter the French-Bulgarian poststructuralist psychoanalytic theorist Julia Kristeva. In Kristeva's acclaimed Powers of Horror (1982), she argues that the common psychological origins of misogyny and Antisemitism lie deeper than castration anxiety, but rather in the "horror" of the abject. ${ }^{10}$ In Kristeva's formulation, castration anxiety represents a secondary manifestation of the original anxiety resulting from the separation from the maternal abject. The Jew, by separating and engaging in, “ ... such an unbearable conjoining of the One and the Other, of Law and Jouissance, of the one who Is and the one who Has" (p. 185), represents an existential threat since, “... if he [the Jew] submits to the Other and draws out of it his mastery as well as his jouissance, is not this dreaded Jew an object of the Father ... his wife as it were, an abjection?" (p. 185). In a sense, the Jew's "choseness" - a choseness that derives not from divine selection, but, according to Kristeva, racial arrogance - leads to an,

... anti-Semitic fantasy [that] relegates ... object to the place of the ab-ject. The Jew: a conjunction of waste and object of desire, of corpse and life, fecality and pleasure ... becomes the feminine exalted to the point of mastery, the impaired master, the ambivalent, the border where exact limits between same and other, subject and object, and even beyond these, between inside and outside, and disappearing hence an Object of fear and fascination. Abjection itself. He is abject: dirty, rotten ... a fecalized, feminized, passivated rot .... (italics in the original, 1982, p. 185)

We now find ourselves in a position to better understand the deeper motivations for the historical pattern of Antisemitic enactments that banned and effectively demonized ritual circumcision (brit milah, literally "covenant of circumcision"). ${ }^{11}$ The Antisemite unconsciously views Jewish circumcision as contributing to a racial emasculation - a cultural castration that symbolically equivocates Jews with women. Fearful of a biblical masculinity that accommodates traditionally feminine characteristics, the Antisemite wishes to "re-masculate" the Jew in their own image (of Greek masculinity) in order to defuse their own unconscious conflicts with powerful, alien, and mysterious women. Therefore, the banning and demonizing of ritual circumcision represents the political manifestation of a collective phantasy that functions to defend against the 
Antisemite's own castration anxiety by repairing what they interpret to be the Jews' castration. The "irrational" Jew thereby becomes transformed into a "rational" Greek through pre-emptive epispasm (an operation that reverses circumcision - see Hall, 1992 for a detailed treatise on the phenomena of epispasm). By transforming Jews into Greeks, or, if you prefer, a "proper" Westerner, since as Phillip Slater (1968) reminds us, "buried beneath every western man is a Greek" (p. 451), the Antisemite betrays their own neuroses that drive their misogynistic world view and unresolved castration anxiety. The historical record, of course, has repeatedly shown that these Antisemitic phantasies are typically frustrated either by the "stiffed-neck", unassimiliatable, culturally obstinate Jew, or by the hyper-secularised, Jewish proto-citizen. This unrequited rage often finds an outlet along a continuum of Antisemitic overtures, with the so-called "soft" Antisemitism consisting of social marginalisation and legal restrictions to more violent manifestations, such as pogrommes and even wholesale genocide.

\section{Sometimes a circumcision is just a circumcision ...}

A frequently ignored consideration regarding prevalent theories around Jewish ritual circumcision and the resultant psychoanalytic interpretive tendencies pivots around the yet un-asked question of whether the ancient Hebrews themselves experienced ritual circumcision in a manner that would lead to these conclusions. To this end it is noteworthy as much as it is ironic that unapologetic "Hebraic" interpretations of the Hebrew Scriptures has generally represented a theoretical blind spot in the psychoanalytic understanding of Jewish ritual circumcision. ${ }^{12}$ The Russian Jewish philosopher Lev Shestov, in his magnum opus Athens \& Jerusalem (1937/1966), indeed warned against the seductive trend to analyse the Bible through Greek optics, posing the question:

How shall we succeed in reading and understanding Scripture not according to the teaching of the great Greek masters, but as they have transmitted to us, by means of the Books of Books ... ? As long as the Bible was exclusively in the hands of the chosen people, this question did always find themselves under the dominion of rational principles and of that technique of thought which has somehow become our second nature, which we consider - without even realizing it - as the immutable conditions for the grasping and possession of truth ... Is a man educated by the Greeks capable of preserving that freedom which is the condition of the right of understanding what the Bible says? (p. 278)

More recently, Clines (1995) has aptly observed that, “... the function of commentary on biblical texts has been to familiarize the Bible, to normalize it to our own cultural standards, to render it as undisturbing as possible, to press it into the service of a different worldview", concluding that, " ... it is the task of scholars, taking a step of critical distance as best they can from their own culture and their personal scripts, to bring back into the foreground the otherness of the familiarized" (italics in the original, p. 33). The task of reading the biblical Scriptures let alone psychoanalytically theorising from a primarily Hebraic context cuts against the grain of standard scholarly inquiries due to the privileging of Greek philosophy and its intellectual heirs, namely pure reason (see Cantz \& Castle, 2013; Miller, 1983).

At this point, it will be instructive to examine the sentiments and motivations that the Bible ascribes to ritual circumcision. The first mention of circumcision is located in Genesis when God addresses Abram:

This is my covenant, which you shall keep, between Me and you and your offspring after you: Every male among you shall be circumcised. You shall be circumcised in the flesh of your foreskins, and it shall be a sign of the covenant between Me and you. He who is eight days old among you shall be circumcised ... So shall my covenant be in your flesh an everlasting covenant. Any uncircumcised 
male who is not circumcised in the flesh of his foreskin shall be cut off from his people; he has broken my covenant. (Gen. 17:10-14)

We find similar Scriptural passages relating to the idiom of "placing one's hand under another thigh" (i.e., another's circumcised organ) as affirming a covenantal relationship between man and his fellow:

And Abraham said unto his servant, the elder of his house, that ruled over all that he had: 'Put, I pray thee, thy hand under my thigh. And I will make thee swear by HaShem, the God of heaven and the God of the earth, that thou shalt not take a wife for my son of the daughters of the Canaanites, among whom I dwell. But thou shalt go unto my country, and to my kindred, and take a wife for my son, even for Isaac.' (Gen. 24: 2-4)

And

And the time drew near that Israel [Jacob] must die; and he called his son Joseph, and said unto him: 'If now I have found favour in thy sight, put, I pray thee, thy hand under my thigh, and deal kindly and truly with me; bury me not, I pray thee, in Egypt.' (Gen. 47: 29)

Erich Wellisch, a British psychiatrist and psychotherapist, in his book Oedipus and Isaac (1954), seems to have headed Shestov's advice when he, for the first time, questioned the theoretical hegemony around the Greek-based psychoanalytic paradigm of the Oedipus complex by focusing on the genetically similar biblical narrative of the Binding of Isaac (Gen. 22), in so doing inviting alternative ways of theorising around biblical circumcision.

According to Freud (1914, 1923a, 1923b, 1924), the successful resolution of the Oedipus complex results from the child internalising reality and phantasy-based parental values and interdictions to form what becomes their ego ideal - a vital component of the superego that benchmarks and in some ways enforces moral standards of behavioural and psychic comportment. More specifically, Freud maintained that the ego ideal develops through the channeling of the libidinal object-love previously reserved for the opposite-sex parent into a narcissistic libido, resulting in a more realistic, balanced, and independent mental organisation of the self. Although Wellisch subscribed to Freud's developmental theory of superego development, he chiefly focused on the father's experience of intergenerational jealousy and competition (what Wellisch preferred to reframe as the "Laius Complex") radically extending the composition of the ego ideal and ergo the superego by including the impact of an, "assum[ed] external moral force" (p. 78), terming this phenomena the "Akedah Motif" - "Akedah" referring to the binding of Isaac in Genesis 22. Abraham, by yielding to God's eleventh hour command to, "Lay not thy hand upon the lad, neither do thou any thing unto him" (Gen. 22:12), rejected the path of psychological determinism and instead internalised the life-affirming message of his Diety. Wellisch's Akedah Motif effectively shifts the focus of oedipal mastery away from a structural compromise formation underwritten by the threat of castration, and instead into that of "instinctual modification". These parent-child dynamics were biblically codified in the covenantal resolution of the Akedah narrative, and are characterised by the wholesale abandonment of paternal aggression and possessiveness and replaced with a peaceful, unambivalent bond of love and trust. Abraham's introjection of an alternative, life-promoting moral attitude illuminates an alternative, more psychologically mature manner of oedipal mastery that deflated father-son rivalries, ensuring that intergenerational continuity be maintained without the specter of unconscious filicidal wishes saturating the family dynamic. Elsewhere, I have elaborated on some of the ways that the Akedah Motif encourages more hopeful and healthy family dynamics

(cf.

Cantz,

2012). 
Here we can also discern a parallel process between God/Abraham and Abraham/Isaac; similar to how Abraham's willingness to sacrifice his most beloved son concretised God's love and trust in Abraham and ended the series of trials of faith that Abraham had endured, Isaac's willingness to be bound on the altar $^{13}$ demonstrated his own covenantal alliance with his father, Abraham. It therefore seems plausible that Isaac's submission to and trust in his father encouraged Abraham's psychological progression. Alternatively stated, the covenantal relationship between Abraham and God, which had also been, in part, forged through circumcision (Gen.17:10-14), extended into Abraham's relationship with his son Isaac. In essence, Abraham's relationship with God became prototypical for the intergenerational investment between fathers and sons in the Hebrew tradition, thereby representing a cultural narrative that dramatically reappraises the developmentally optimal sequencing and resolution of the Oedipus complex.

This introjection of a divine imago, while compelling, requires some further explication, particularly around the role played through ritual circumcision. Our challenge here is to interpret biblical ritual circumcision divorced from the prevailing Greek-based understanding that has saturated the lens through which psychoanalysis and allied disciplines have traditionally viewed this rite. To this end, the theoretical distinction between covenant rather than conflict cannot be overstated. This critical project of establishing an everlasting covenant - a special parallel relationship between God and man and then between man and man, figures most prominently; based on competing cultural myths involving castration, one would expect to discern more overt themes of violence. On the contrary, though, there is no detectable trace of filial competition in the biblical literature such as we find in Hesiod's Theogony where Chronus conspires with his mother, Gai, to castrate their maniacal father, Uranus (Theogony 160-185) as well, of course, as the Oedipus myth itself with the filicidal efforts of Laius.

This everlasting covenant becomes symbolised through ritual circumcision, which, extending Wellisch's project, Kaplan (2002) has interpreted this rite as a non-injurious cross-generational reminder of the modulated aggressive instinct (p. 17). No need exists to fear a father who has demonstrated filicidal restraint and who expressly desires for his son to continue his spiritual legacy. In effect, the act of ritual circumcision functions to quell intergenerational competition, situating the child at the leading edge of a teleological unfolding of history.

For the individual who embodies a predominantly Hebraic world view, ritual circumcision represents the parallel covenantal alliance forged between generations and established with God, or if you prefer, a sacrosanct, life-promoting moral code that promotes intergenerational continuity. There is no expectation of ritual circumcision leading to castration anxiety or encouraging misogynistic attitudes since the Hebraic experience of this rite undercuts these phantasies by modulating the father's aggressive and competitive proclivities towards their sons, and, in turn, producing heirs who are disinclined to compete with their father over resources. Therefore, since ritual circumcision does not threaten the Hebraic conceptualisation of masculinity, and since biblical man neither fears the feminine other nor regards himself as emasculated as a result of being circumcised, misogynistic sequela should be purged from the constellation of oedipal assumptions that have mostly gone unquestioned in standard psychoanalytic metatheory, and has certainly contributed to skewed mainstream psychoanalytic explanations for the development and perpetuation of Antisemitism.

We can therefore conclude that the misogynistic, gyno-phobic preoccupations of the Classical world have been superimposed onto the Jew and his circumcision, at least partially contributing to the constellation of psychic determinants that have underwritten Antisemitic attitudes and behaviours throughout the past two thousand years up to and including today. 


\section{Notes}

1. I have chosen to consistently spell "Antisemitism" without a hyphen in order to encourage a movement away from the sterile anthropological connotations that "anti-Semitism" carries. This decision has been inspired by the forward-thinking Christian theologian Franklin H. Littell (1978), who reminds us that on occasion "owlish" individuals will protest that "the Arabs" cannot technically be anti-Semites because they are themselves Semitic. The hyphen, therefore, acts as a linguistic distraction from the plain meaning of the word: hatred of Jews (Judenhass).

2. Compare this to the Antisemitic, racialist writings of Houston Steward Chamberlain - an English author of books on political philosophy, natural science, and son-in-law of the German composer Richard Wagner - who wrote that Jews are a "counter-race". From G. G. Otto, Der Jude als Weltparasit ("The Jew as parasite") (Munich: Eher Verlag, 1943).

3. After reviewing a draft manuscript of Sex and Character, Freud (1909), while acknowledging Weininger's unquestionable intelligence, nevertheless regarded him as a "sexually deranged" neurotic.

4. "In classical Athens the rift between the notions of sex for procreation and sex for pleasure and release, between Demeter and Aphrodite, was so complete that it left its marks on almost all facets of organised society" (Keuls, 1985, p. 205).

5. On this point we find Weininger echoing the view of Semonides who likewise recognised the necessity of women, but only as a means to having children, not as full human beings in their own right.

6. Unlike Lombroso, who never publically acknowledged his Jewish roots in his writings, Weininger, who had previously converted to Protestantism, in a footnote reminded his readers of his own Jewish heritage.

7. In this regard it is significant that the Targum Onkelos on Gen. 25:27 - the authoritative Aramaic translation of the Hebrew scriptures (authored by the famous convert Onkelos, c. 35 - 120 CE) - idiomatically translates this section as: "And the two boys grew up, and Esau was a skilled hunter, a man who went out to the fields, and Jacob was a perfect man who frequented the schoolhouse."

8. The historical uniqueness of this Hebraic de-emphasis of physicality as the centerpiece of masculinity can be observed through the reactions of the Greeks, who experienced this cultural trend as alien. The Romano-Jewish scholar, historian, and hagiographer Flavius Josephus cites the Greek historian, Agatharchides of Cnidus, who recounted that:

There is a nation called the nation of the Jews, who inhabit a city strong and great, named Jerusalem. These men took no care, but let it come into the hands of Ptolemy, as not willing to take arms, and thereby they submitted to be under a hard master, by reason of their unseasonable superstition. (Antiquities, XII: 6)

Josephus again quotes Agatharchides in Against Apion where his rhetoric concerning Ptolemy's siege of Jerusalem betrays blatantly Antisemitic overtones: “... these men, in observing this mad custom of theirs, instead of guarding their city, suffered their country to submit itself to a bitter lord; and their law was openly proved to have commanded a foolish practice" (Against Apion 1.23). The tactics that led to Ptolemy's first conquest of Jerusalem in 312 BCE (he twice re-conquered Jerusalem: in $312 \mathrm{BCE}$ and then again in $302 \mathrm{BCE}$ ) were copied nearly 300 years later in $37 \mathrm{BCE}$ by the Romans under Herod the Great.

The message of Josephus' narrative is clear: the Ptolemaic forces and then the Romans felt that they had trounced the Jewish nation without encountering an iota of resistance simply by playing into the Jew's superstitious vulnerabilities of remaining passive by refusing to bear arms in self-defense on the Sabbath. In short, the Jews represented an easy mark every seventh day. Notably, in response to the massacre of thousands of men, women, and children who refused to defend their lives on the Sabbath, in 167 BCE Mattathias, the patriarch of the Hasmonaean dynasty decreed that the Jewish people could henceforth defend themselves on the Sabbath day - a decree that "... continues among us to this very day" (Antiquities XII vi 276-277; 1 Macc. 2:29-41). Indeed, we later find Talmudic and rabbinical rulings, however, carved-out self-defense exemptions of the Sabbath laws (cf. Sanhedrin, 72a; Sotah 44b; Maimonides, Mishneh Torah, Laws of the Sabbath 2:23; Shulkhan Arukh, Orah Hayyim 329:6, 7; Arukh HaShulkhan He'Atid, Hilkhot Melakhim 74:3-4). Some scholars, however, question whether there was ever a Jewish-sponsored ban on self-defense on the Sabbath, observing that the idea that there was ever such a prohibition lacks reliable sourcing in classical Jewish legal texts. To be sure, biblical man qua Judaism did not possess Spartan-like sensibilities when it came to warring, but neither did they balk when faced with existential threats. 
9. The ancient Greeks were likewise not shy about lampooning the figure of Moses. The Greek rhetorician Apollonius Molon (first-century BCE) defamed him as a "conjurer and a deceiver" - an imposter of Egyptian origins who taught evil to the world. These remarks are tame compared to the writings of the scholar Lucius Cornelius Alexander Polyhistor - also called Alexander of Miletus (first Century $\mathrm{BCE}$ ), who, probably mockingly, made the extraordinary statement that Moses was in fact a woman: "And about Rome [Alexander wrote] five books, in which he states that there a Hebrew woman Moso, who composes the Law of the Hebrews" (in Stern, 1974).

10. Def. of "abject": Our reaction to a threatened breakdown in meaning caused by the loss of the distinction between subject and object or between self and other.

11. For instance, in 168 BCE, Antiochus IV Epiphanes of Syria enacted the death penalty on Jews who chose to circumcise their newborn sons and in CE 135 the Roman Emperor Hadrian enacted similar decrees. In more contemporary times institutional restrictions on Jewish circumcision again became fashionable during the Spanish Inquisition as well as under the former Soviet government and under the Nazi socialist party.

12. In a similar vein, Scolnic (2010) who, within the context of discussing the Hasmonaean Dynasty, challenges the prevailing scholarly momentum regarding the default assumption in academia that the biblical tradition has essentially been historically whitewashed to distort Hellenistic motives. Also see the work of Yoram Hazony (2012), who argues that the biblically innate Hebraic brand of political theory and philosophy rightfully deserves a prominent place in academic and scholarly discourse.

13. According to mainstream rabbinic biblical exegesis, Isaac was 37 years old at the time of his binding, and therefore a mature man with the physical and moral fortitude to put up a resistance if he had sensed that his father Abraham harbored nefarious motives (see Cantz, 2012).

\section{ORCID}

Paul Cantz (D) http://orcid.org/0000-0002-5766-6159

\section{References}

Alexander, F. G. (1923). Castration complex in the formation of character. International Journal of Psychoanalysis, 4, 11-42.

Aristotle. (1984). Economics. In J. Barnes (Ed.), The complete works of Aristotle: The revised Oxford translation (Vol. II, pp. 2130-2151). Princeton, NJ: Princeton University Press.

Cahill, T. (1998). The gift of the Jews: How a tribe if desert nomads changed the way everyone thinks and feels. New York, NY: Doubleday.

Cantz, P. (2012). Towards a biblical psychoanalysis: A second look at the first book. Mental Health, Religion \& Culture, 15, 779-797. doi: 10.1080/13674676.2011.637167

Cantz, P., \& Castle, M. (2013). A psycho-biblical response to death anxiety: Separation and individuation dynamics in the Babel narrative. Journal of Psychology \& Theology, 41, 327-339.

Cantz, P., \& Kaplan, K. J. (2013). Cross cultural reflections on the feminine "other": Hebraism and Hellenism redux. Pastoral Psychology, 4, 486-496. doi: 10.1080/14486563.2013.878258.

Clines, D. J. (1995). Interested parties: The ideology of writers and readers of the Hebrew Bible (Vol. 1). Sheffield: Sheffield Academic Press.

de Beauvoir, S. (1949/1972). The second sex. (H. M. Parshley, Trans.). New York, NY: Penguin.

Durant, W. (1926). The story of philosophy. New York, NY: Simon \& Schuster.

Freud, S. (1909). Analysis of a phobia in a five-year-old boy. In J. Strachey (Ed.), The Standard Edition of the Complete Psychological Works of Sigmund Freud (pp. 5-149). London: Hogarth Press.

Freud, S. (1914). On narcissism: An introduction. In J. Strachey (Ed.), The Standard Edition of the Complete Psychological Works of Sigmund Freud (pp. 67-102). London: Hogarth Press.

Freud, S. (1923a). The ego and the id. In J. Strachey (Ed.), The Standard Edition of the Complete Psychological Works of Sigmund Freud (pp. 12-59). London: Hogarth Press.

Freud, S. (1923b). The infantile genital organisations: An interpolation into the theory of sexuality. In J. Strachey (Ed.), The Standard Edition of the Complete Works of Sigmund Freud (pp. 141-148). London: Hogarth Press.

Freud, S. (1924). The dissolution of the Oedipus complex. In J. Strachey (Ed.), The Standard Edition of the Complete Works of Sigmund Freud (pp. 173-179). London: Hogarth Press. 
Freud, S. (1939). Moses and monotheism. In J. Strachey (Ed.), The Standard Edition of the Complete Works of Sigmund Freud (pp. 7-137). London: Hogarth Press.

Gilman, S. (1991). Reading Freud in English: Problems, paradoxes, and a solution. International Review of Psycho-Analysis, 18, 331-344.

Hall, R. G. (1992). Epispasm: Circumcision in reverse. Bible Review, 8, 52-57.

Hatch, E. (1957). The influence of Greek ideas on Christianity. New York, NY: Harper \& Brothers.

Hazony, Y. (2012). The philosophy of Hebrew scripture. Cambridge, MA: Cambridge University Press.

Herodotus. "Artemisia at Salamis." The History. 480 B.C.E. (George Rawlinson, Trans.). Ancient History Sourcebook. Dec. 2003. Retrieved from http://www.fordham.edu/halsall/ancient/480artemisia.html.

Hesiod. (c. 700 BCE/ 2006). Theogony, works and days, testimonia. (G. W. Most, Ed. and Trans.). Cambridge, MA \& London: Harvard University Press.

The Holy Scriptures. (1917). Philadelphia, PA: Jewish Publication Society of America.

Jonte-Pace, D. (2001). Speaking the unspeakable: Religion, misogyny, and the uncanny mother in the Freud's cultural texts. Berkeley, CA: University of California Press.

Kaplan, K. J. (1990). Isaac and Oedipus: A re-examination of the father-son relationship. Judaism, 39, 73-81.

Kaplan, K. J. (2002). Isaac versus Oedipus: An alternative view. Journal of the American Academy of Psychoanalysis, 30, 707-717. doi: 10.1521/jaap.30.4.707.24203

Kaplan, K. J. (2011). Obedience and disobedience/rebellion in biblical versus Greek Narratives: Toward a biblical psychology. Pastoral Psychology, 60, 659-670.

Kaplan, K. J., \& Cantz, P. (2014). Israel: 'occupier' or 'occupied'? The psycho-political projection of Christian and post-Christian supersessionism. Israel Affairs, 20, 40-61. doi:10.1080/13537121.2013. 863082.

Keuls, E. (1985). The reign of the phallus: Sexual politics in ancient Athens. New York, NY: Harper Row.

Kristeva, J. (1982). Power of horror: An essays on abjection. (L. Roudiez, Trans.). New York, NY: Columbia University Press.

Littell, H. F. (1975). The crucifixion of the Jews. New York, NY: Harper \& Row.

Lombroso, C. (1891). L'uomo di genio in rapporto alla psichiatria [Man of genius]. London: Walter Scott.

Lombroso, C. (1894). L'antisemitisomo e le scienze moderne [The anti-semitism and modern science]. Turin: L. Roux and C. Publishers.

Lombroso, C. \& Ferrero, G. (1903). La donna delinquent: la prostituta e la donna normale [Criminal woman, the prostitute, and the normal woman]. Torino: Fratelli Bocca Editori.

Miller, J. W. (1983). Psychoanalytic approaches to biblical religion. Journal of Religion and Health, 22, 1929.

Nietzsche, F. W. (1879/2006). Human, all too human: A book for free spirits. (H. Zimmern \& P. V. Cohn, Trans.). Mineola, NY: Dover.

Nietzsche, F. W. (1886/1966). Beyond good and evil. (W. Kaufmann, Trans.) New York, NY: Vintage Books.

Nietzsche, F. W. (1910/1968). The will to power. (W. Kaufmann \& R. J. Hollingdale, Trans.) New York, NY: Vintage Books.

O'Neal, W. (1993). The status of women in ancient Athens. International Social Science Review, 68, 115-121.

Plato. (2003). The Republic. (Desmond Lee, Trans.). London: Penguin Books.

Reik, T. (1946). Ritual, psychoanalytic studies. New York, NY: International Universities Press.

Roper, H. T. (1953). Hitler's table talk. London: Macmillan.

Rubenstein, R. L. (1968). The religious imagination: A study in psychoanalysis and Jewish theology. Indianapolis, IN: The Bobbs-Merrill.

Schlossman, H. H. (1966). Circumcision as defense: A study in psychoanalysis and religion. The Psychoanalytic Quarterly, 35, 340-356.

Scolnic, B. E. (2010). Judaism defined: Mattathias and the destiny of his people. Lanham, MD: University Press of America.

Semonides of Amorgos. (1961). In Greek Lyrics (R. Lattimore, Trans.) (2nd ed., pp. 8-11). Chicago, IL: University of Chicago Press.

Shestov, L. (1937). Athens and Jerusalem. (B. Martin, Trans.). New York, NY: Simon \& Schuster.

Slater, P.E. (1968). The glory of Hera: Greek mythology and the Greek family. Boston, MA: Beacon Press.

Stern, M. (1974). Greek and Latin authors on Jews and Judaism. Jerusalem: Israel Academy of Sciences and Humanities.

Trible, P. (1990). Genesis 22: The sacrifice of Sarah. Valparaiso: Valparaiso University Press.

Vasillopulos, C. (2008). The degradation of Athenian women in the phallicratic polis. International Journal of Social Inquiry, 1, 5-28. 
Weininger, O. (1903/2005). Sex and character (Ladislaus Löb, Trans.). Bloomington, IN: Indiana University Press.

Wellisch, E. (1954). Isaac and Oedipus: Studies in biblical psychology of the sacrifice of Isaac. London: Routledge and Kegan Paul.

Xenophon. (1912-1913). "On Men and Women." Oikonomikos. c. 370 B.C.E. In William Stearns Davis (Ed.), Readings in ancient history: Illustrative extracts from the sources (Vols. 2, pp. 265-271) I. Boston, MA: Allyn and Bacon. 